\title{
Correction to: Hypoxemia and prone position in mechanically ventilated COVID-19 patients: a prospective cohort study
}

\author{
Osama Abou-Arab, MD, PhD • Guillaume Haye, MD • Christophe Beyls, MD • \\ Pierre Huette, MD • Pierre-Alexandre Roger, MD • Mathieu Guilbart, MD • \\ Michaël Bernasinski, MD - Patricia Besserve, MD - Faouzi Trojette, MD • \\ Hervé Dupont, MD, PhD · Vincent Jounieaux, MD, PhD · Yazine Mahjoub, MD, PhD
}

Published online: 18 December 2020

(C) Canadian Anesthesiologists' Society 2020

\section{Correction to:}

Can J Anesth/J Can Anesth

https://doi.org/10.1007/s12630-020-01844-9

This article was updated to replace an incorrect version that was published due to an error in the production process.
Publisher's Note Springer Nature remains neutral with regard to jurisdictional claims in published maps and institutional affiliations.

The original article can be found online at https://doi.org/10.1007/ s12630-020-01844-9.

O. Abou-Arab, MD, PhD - G. Haye, MD - C. Beyls, MD .

P. Huette, MD - P.-A. Roger, MD - M. Guilbart, MD .

M. Bernasinski, MD · P. Besserve, MD - F. Trojette, MD .

H. Dupont, MD, PhD · Y. Mahjoub, MD, PhD ( $\square)$

Department of Anesthesia and Critical Care Medicine, Amiens

University Medical Center, Amiens, France

e-mail: mahjoub.yazine@chu-amiens.fr

V. Jounieaux, MD, PhD

Respiratory Department, Amiens University Medical Center,

Amiens, France 